\title{
MICROSCOPIC ANALYSIS OF THE DIAPHRAGM. CASE REPORT
}

Julio Cesar Domenciano, Paulo Roberto Veiga Quemelo, Maria Jose Silvino

Universidade de Franca - UNIFRAN, Programa de Promoção de Saúde, Franca, SP.

\begin{abstract}
The diaphragm is the most important muscle of respiration. The aim of this study was to analyze the cell types that constitute the human diaphragm at different ages. For this purpose, it was collected human tissue samples cadaveric fetal diaphragm, adult and elder. The material was processed and analyzed by optical microscopy and transmission electron. The results of the diaphragm suggest that the structure is altered conformation and distribution in the surface of collagen fibrils in the fundamental extracellular substance of the amount and diameter of the muscle fibers at the ages studied.
\end{abstract}

Keywords: diaphragm, striated muscle, age groups, microscopy.

\section{ANÁLISE MICROSCÓPICA DO DIAFRAGMA. RELATO DE CASO}

\section{RESUMO}

O diafragma é o músculo mais importante da respiração. Assim, o objetivo do presente estudo foi analisar a distribuição e os tipos celulares que constituem o diafragma humano em diferentes idades. Para tanto, foram coletados amostras de tecido humano cadavérico do diafragma fetal, adulto e idoso. O material foi processado e analisado por microscopia óptica e eletrônica de transmissão. Os resultados obtidos do diafragma sugerem que a estrutura sofre alterações na distribuição e conformação da superfície das fibrilas de colágenos, na quantidade da substância extracelular fundamental e no diâmetro das fibras musculares nas idades estudadas.

Palavras-chave: diafragma, músculo estriado, grupos etários, microscopia. 


\section{INTRODUCTION}

The musculotendinous diaphragm is a dome shaped wall, which separates the chest cavity from the abdominal cavity and has a complex embryonic origin. The diaphragm is a mixed muscle and has $40 \%$ of its type I fibers, $27 \%$ type Ila and $34 \%$ type IIb. This constitution is due to its function and constant contraction to maintain ventilation. However, due to the combination of voluntary and involuntary contractility, some inquiries about its constitution are pointed and few studies address this aspect. With increasing age and in cases of diaphragmatic immobility, trophic and metabolic changes can occur, such as atrophy and transformation of slow twitch muscle fibers in fast-twitch fibers ${ }^{1-4}$.

In this context and taking into account the importance of the diaphragm in breathing, more detailed study of the microscopic aspects of its constituent parts seems to be appropriate. Thus, the aim of this study was to analyze the microscopic and ultra structural distribution difference and the cell types that constitute the regions, muscle and tendon of the fetal, adult and elderly human diaphragm.

\section{MATERIALS AND METHODS}

The study was approved by the Ethics Committee of the Faculty of Medicine of
Ribeirão Preto - USP, under protocol number 4077/2003. After the consent of legal guardian, the cadaveric material was collected at the Center for Forensic Medicine, Faculty of Medicine - University of São Paulo.

Three human cadavers ware included in this case report. Male fetus with twenty-six weeks that died by spontaneous miscarriage; adult male (obese) with 24 years old who died of heart laceration probably by hypertension; elderly female with 91 years old that died by hemorrhagic brain stroke.

The segments of muscle and tendon of the diaphragm of three human cadavers were collected (male fetus; adult male and elderly female). The diaphragm fragments were collected with maximum time of death for 6 hours. The size of each sample did not exceed $10 \times 10 \mathrm{~mm}$ square, as shown in Figure 1.

The fragments were pre-fixed and dehydrated in alcohol. Subsequently, the material was to resin (EXPOSE ${ }^{\circledR}$ ) and taken to an oven at $72^{\circ} \mathrm{C}$ for polymerization. The semithin serial sections of $40 \mu \mathrm{m}$ were made and stained with toluidine blue. The material was analyzed using a light microscope (Leica $^{\circledR}$ Model MPS-60).

Later we performed ultra-thin serial sections of $80 \mathrm{~nm}$ for transmission electron microscopy. The material was stained and impregnated in uranyl acetate and soon after 
in lead nitrate and analyzed $\left(\mathrm{GO}^{\circledR}\right.$ model 1010).

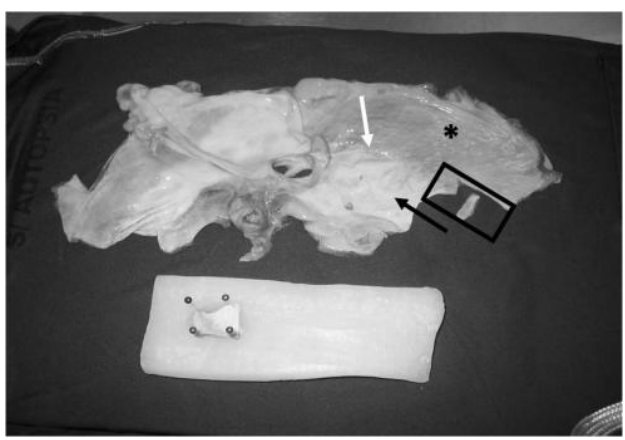

Figure 1. Photograph showing a large area of the adult human diaphragm. It shows the following structures: Part tendon (black arrow), the transitio' region between the center tendon/muscle (white arrow), muscle part (asterisk) and collection region of the fragment shown below (rectangle black).

\section{RESULTS - CASE REPORT}

Description of the histological aspects of fetal diaphragm

The analysis of the muscle of the human diaphragm of the fetus by optical microscopy, it was observed that muscle tissue is divided into fascicles (bundles) surrounded by loose connective tissue (perimysium) with presence of arteries and veins. It was observed that muscle fibers showed a smaller diameter and a greater number within a bundle diaphragm in fetal as well as each muscle fiber, which appear as dots within the sarcolemma. It was also demonstrated increased amount of connective tissue between the muscle bundles (Figure 2A). The analysis by electron microscopy of the diaphragm was observed homogeneous profile of fibrils, uniformity of the diameter of the fibrils and the presence of large quantities of extracellular matrix and collagen fibrils (Figure 2B).

Description of the histological aspects of adult diaphragm

The analysis by optical microscopy in the adult diaphragm, it was also found the same divisions of fascicles surrounded by connective tissue. However, as shown in Figure $2 \mathrm{C}$, the adult muscle fibers had greater diameter with uniform size and distribution within the fascicles with smaller amount of tissue. The analysis the diaphragm adult fibrils by electron microscopy was observed varying diameters but with larger size when compared to the fetus. The fibers in adult presented in widely dispersed in the extracellular matrix (Figure 2D).

Description of the histological aspects of the elderly diaphragm

The analysis by optical microscopy in the elderly diaphragm, it was also found the same divisions of fascicles surrounded by loose connective tissue. However, as shown in Figure 2E, the muscle fibers of elderly showed a smaller diameter without uniform diameter distribution in fascicles, with lots of connective tissue and large amounts of 
adipose tissue. The analysis by electron microscopy of the diaphragm elderly it can be observed fibrils of varying diameters, smaller than in the adult, but similar to that observed in the fetus with the shape of very varied surface, widely dispersed fundamental extracellular matrix (Figure $2 \mathrm{~F}$ ).
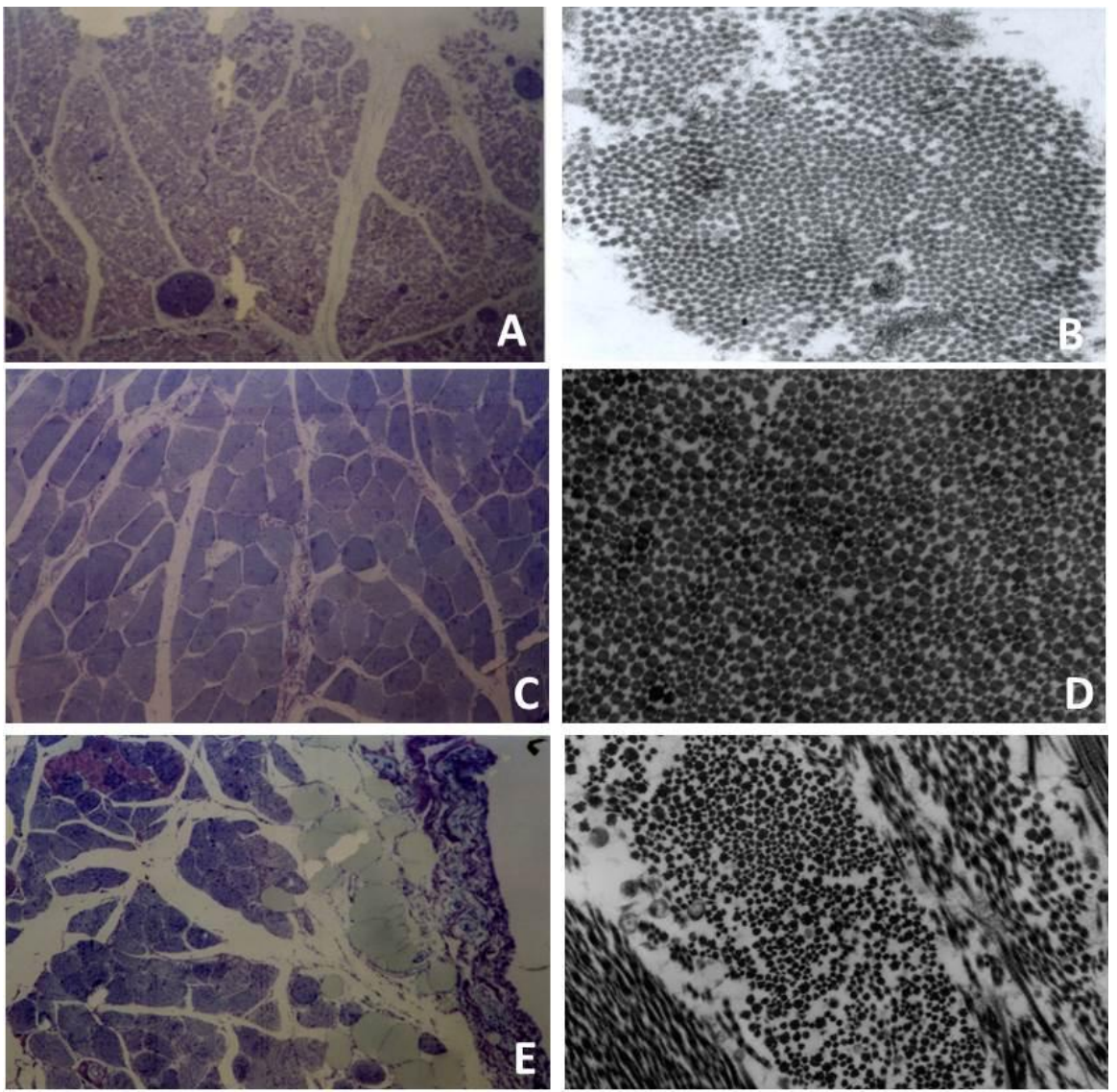

Figure 2. A - Photomicrograph of the diaphragm in cross section of the fetus with 26 weeks of age. Note large amount of muscle fibers in fascicles, and plenty of connective tissue between muscle fibers - 100X. B - Electron Microscopy in cross section showing the collagen fibers of the fetus 14,000X. C - Photomicrograph of cross section of the adult diaphragm muscle at 24 years old. Note the size of muscle fibers - 100X. D - Electron Microscopy cross section of collagen fibrils of an adult male with 24 years - 14.000X. E - Photomicrograph of cross section of the diaphragm muscle of an adult female with 91 years old. Note small muscle fibers, without uniformity regarding the size of the diameter and shape. Note the abundance of connective tissue between the muscle bundles 100X. F - Electron Microscopy cross-section of collagen fibrils in the elderly - 14000X.

\section{DISCUSSION}

The electron microscopy of the diaphragm tendon showed that the collagen fibrils present diverse aspects when compared between different subjects in this study. It was observed a slight variation in 
the form of muscle fibers. Comparing the images of subjects, it was possible to observe a difference in the diameter of collagen fibrils with a smaller diameter in the fetus, increasing the diameter of in the adult and decline again in the elderly. The arrangement of collagen fibers also undergo changes, as well as the amount of fundamental substance which is higher in the fetus, decreases in adults and increases again in the elderly.

The smaller diameter of muscle fibers within the bundle observed in the fetus could be related to the lack of muscular activity. Similarly, the large amount of fundamental extracellular matrix and disorganization of the fibrils in the elderly can be characteristic of old age and indicate little activity that the diaphragm usually develops at this stage of life. There is evidence that in old rat occur a decrease in the thickness of primary dendrites in motoneurons that innervating the diaphragm muscle ${ }^{5}$. The literature suggests that subjects undergoing mechanical ventilation show rapid atrophy and proteolysis of diaphragm, within a period of 18 hours at 69 hours $^{6}$. On the other hand, in a study with rats, it was observed that aging does not cause morphological changes in muscle structure of the animals when compared with young rats, probably due to daily function exerted by this muscle ${ }^{2,4}$.

Different dysfunctions can be observed in diaphragm, such pneumonia, tumors, muscular dystrophies and others. Diaphragm pathology can be diagnosis by ultrasound and microscopy analyses ${ }^{7,8}$. The differences observed in microscopy analyses between the ages in the present study can be due to the individual characteristics. The observations and reports were based on images obtained that all were performed with the same size. However, as the present study is a case report, the results show the some limitations, but can suggest that standard changes occur in these different ages. Thus, on the record presented is possible to suggest that the muscular part of the diaphragm showed significant difference in the muscle fibers, as the diameters and their arrangement within the perimysium and the amount of connective tissue between the fascicles at different ages.

\section{REFERENCES}

1. Gardner E, Gray DJ, O'Hilly R. Anatomia. 4.ed. Rio de Janeiro: Guanabara Koogan, 1998.

2. Leme LEG, Rodrigues CJ, Rodrigues AJ, de Carvalho Filho ET, Leme MD, Leivas TP. Estudo comparativo do envelhecimento do sistema capilar dos músculos: diafragma e reto anterior do abdome em ratos. Futuro modelo para o estudo de atividade física? Acta Ortop Bras. 2005;13(4):186-188. http://dx.doi.org/10.1590/S1413$\underline{78522005000400007}$

3. Sandoval JA, Gil F, Arencibia A, Ayala I, Vazquez YJ. Estudio Histoquímico y Morfométrico de la Población Fibrilar del Músculo Diafragma. Parte I: Caballo y Perro. Anat Histol Embryol. 1995;24(4):269-274. 
http://dx.doi.org/10.1111/j.1439-

0264.1995.tb00047.x

4. Santos-Júnior, FFU, Alves JSM, Machado AAN, Carlos PS, Ferraz ASM, Barbosa R et al. Alterações morfométricas em músculo respiratório de ratos submetidos à imobilização de pata. Rev Bras Med Esporte. 2010;16(3):215-218.

http://dx.doi.org/10.1590/S1517-

$\underline{86922010000300012}$

5. Miyata $H$, Suzuki $T$, Maruyama A, Wada N. Age-related three-dimensional morphological changes in rat motoneurons innervating diaphragm and longissimus muscles. Anat Histol

Embryol. 2008;37(5):394-9.

http://dx.doi.org/10.1111/j.1439-

0264.2008.00873.x

6. Levine S, Nguyen T, Taylor N, Friscia ME, Budak MT, Rothenberg $P$ et al. Rapid disuse atrophy of diaphragm fibers in mechanically ventilated humans. N Engl J Med. 2008;358(133):1327-35. http://dx.doi.org/10.1056/NEJMoa070447

7. Sarwal A, Walker FO, Cartwright MS. Neuromuscular ultrasound for evaluation of the diaphragm. Muscle Nerve. 2013;47(3):319-29.

http://dx.doi.org/10.1002/mus.23671

8. McCool FD, Tzelepis GE. Dysfunction of the diaphragm. N Engl J Med. 2012;366(10):932-942.

http://dx.doi.org/10.1056/NEJMra1007236

Recebido para publicação em 01/09/2014

Revisado em 26/01/2015

Aceito em 18/03/2015 